\title{
Influence of Different Reline Materials and Processing Methods on Flexural Strength of Denture Base Material
}

\begin{abstract}
SUMMARY
Background/Aim: Relining is defined as the procedure used to resurface the tissue side of a denture with new base material, thus producing an accurate adaptation is provided at the denture foundation area. During mastication, relined dentures have to withstand masticatory forces to prevent fracture. The aim of this study was to evaluate the flexural strength of acrylic resin denture base relined with different methods and materials. Material and Methods: Fourteen experimental groups and one control group were determined to consider different reline materials and processing methods. Acrylic resin specimens were prepared with the dimensions of $65 x 10 x 1.5$ $\mathrm{mm}$ and reline materials (1.5 mm thickness) were placed on acrylic resins. Reline material was not used in control group specimens. Flexural strength values of relined and control specimens were measured with three-point bending test at a speed of $5 \mathrm{~mm} / \mathrm{min}$. Data were analyzed with using one way Anova and Student $t$ tests. Results: The highest flexural strength values were shown in control group $(86.51 \pm 1.08 \mathrm{MPa})$. There were significant differences among relined specimens $(p<0.05)$. For the relined specimens, the highest flexural strength values were found in the relined specimens with denture base

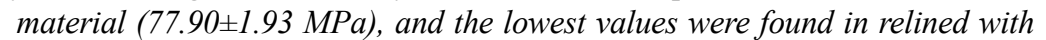
autopolymerize acrylic material (59.81 $\pm 1.50 \mathrm{MPa})$. Conclusions: Relining of the heat cure denture base material significantly decreases the flexural strength for all processing methods and materials.
\end{abstract}

Key words: Denture Base, Flexural Strength, Relining

\begin{abstract}
Ozlem Gurbuz Oflezer ${ }^{1}$, Hakan Bahadır ${ }^{2}$, Senem Ünver ${ }^{3}$, Ceyhan Oflezer ${ }^{4}$

${ }^{1}$ Department of Prosthodontics, Bahcelievler Oral and Dental Health Hospital, Ministry of Health, Bahcelievler, Istanbul/Turkey

${ }^{2}$ Private Practice, Bahcelievler, Istanbul/Turkey ${ }^{3}$ Department of Prosthodontics, Gazi University, Faculty of Dentistry, Emek, Ankara/Turkey ${ }^{4}$ Department of Anesthesiology, Bakirkoy Training and Research Hospital for Psychiatry, Neurology and Neurosurgery, Istanbul/Turkey.
\end{abstract}

ORIGINAL PAPER (OP)

Balk J Dent Med, 2021;108-113

\section{Introduction}

Polymethyl methacrylate (PMMA) materials are most commonly used to fabricate of removable prosthetic restorations. Easy manipulation, low water absorption, compatability and aesthetic appearance are the important advantages of $\mathrm{PMMA}^{1,2}$. Also, these polymers enable to reline of denture base to improve the fitting in case of bone resorption ${ }^{3}$.

Residual ridge resorption, which is an inevitable process, occurs after tooth extraction especially first three months and the amount of resorption slows down in time ${ }^{4}$. Besides, some local and systemic factors such as anatomic, metabolic, psychosocial and mechanical can affect the process ${ }^{4-6}$. As a result of residual ridge resorption, function, stability and retention of removable prosthesis are impaired by decrease of fitting ${ }^{4}$. Relining procedure may be required to improve the adaptation to the supporting tissues of complete, partial and overdenture prosthesis $^{7-9}$.

The strength of relined dentures is affected by denture base polymer, relining material and their adhesion at the interface ${ }^{10}$. Due to weak bonding, bacterial invasion,staining, delamination may occur between the denture base and the lining material, as well as decreased mechanical strength. ${ }^{9,11}$. The composition and processing technic are determinants of mechanical properties of the relining materials ${ }^{12,13}$. Generally, relining materials 
contain methyl methacrylate (MMA), which is similar to PMMA denture base, to increase the bond strength ${ }^{14}$.

Several methods can be performed to analyse the strength of relined denture materials such as impact strength and flexural strength ${ }^{10,14,15}$. During mastication, denture base is exposed to flexural stresses and it was observed that the flexural stresses can cause the formation of a crack, which results fracture of denture base $^{16}$. Therefore, the flexural strength of materials is important parameter for clinical success of prosthetic restorations.

The aim of this in vitro study was to evaluate the flexural strength of acrylic resin denture base, which was relined with different materials and processing technics.
The null hypothesis was that denture relining materials has no effect on the flexural strength of relined denture base.

\section{Material and Methods}

The brand and code names, manufacturers, compositions of the materials used in this study are shown in Table 1. Fourteen groups were determined according to the reline material and processing methods, and a control group were formed. Specimens were prepared according to International Standards Organization Specification No.20795-1:2013 for the denture base polymers ${ }^{17}$.

Table 1. Materials used in this study

\begin{tabular}{|c|c|c|c|c|c|}
\hline Brand & Code & Manufacturer & Feature & Powder & Liquid \\
\hline \multirow{4}{*}{ Meliodent } & \multirow{4}{*}{ M } & Hergeus Kulzer & \multirow{4}{*}{$\begin{array}{l}\text { Rapid Heat Polymerised } \\
\text { Acrylic Resin }\end{array}$} & Methyl methacrylate & $\begin{array}{l}\text { Methyl methacrylate } \\
\text { Glycol dimethacrylate }\end{array}$ \\
\hline & & GmbH D-63450 & & & Dimathol D thluidino \\
\hline & & & & & \\
\hline & & & & N-octyl methacrylate & \\
\hline \multirow{3}{*}{$\begin{array}{l}\text { Meliodent } \\
\text { Rapid Repair }\end{array}$} & \multirow{3}{*}{ MO } & & \multirow{3}{*}{$\begin{array}{l}\text { Autopolymerised } \\
\text { Acrylic Resin }\end{array}$} & Methyl methacrylate & Methyl methacrylate \\
\hline & & $\begin{array}{l}\text { Heraeus Kulzer } \\
\text { GmbH D-63450 }\end{array}$ & & N-octyl methacrylate & Glycol dimethacrylate \\
\hline & & $\Pi$ & & Benzoil peroxide & Dimethyl P-toluidine \\
\hline
\end{tabular}

Acron-S

A Howmedica Austenal Heat Polymerised Acrylic Dental Products, Resin

Heat Polymerised,

Lucitone 199

L Dentsply York Division, Usa

Triad Reline Material

\section{T Dentsply York} Division, Usa

Visible Light-Polymerized Paste-Type Resin

Acron-Mc
Gc-Dental Ind. Corp. Microwave-Polymerised Tokyo-Japan Acrylic Resin
Methyl methacrylate

Ethylene dimethacrylate

Methacylate copolymers, a polyfunctional monomer such as ürethane dimethacrylate and silica filler

Polymethylmethacrylateethylacrylate

Methyl methacrylate

copolymer
Ethylene dimethacrylate 


\section{Preparation of Bulk Denture Resin Specimens}

Six denture resin specimens were prepared with dimensions of $65 \times 10 \times 3 \mathrm{~mm}$ for control group and 84 denture resin specimens were prepared with dimensions of $65 \times 10 \times 1.5 \mathrm{~mm}$ for relining procedures. The cast molds were made by using brass blocks. Heat polymerized polymethyl methacrylate material was placed into the cast mold and were polymerized according to the manufacturer's recommendation. All of the specimens was smoothed with 600 -grit $\mathrm{SiC}$ paper and the dimensions of specimens were measured with a caliper (Mitutoyo Sul, Americana, Suzano, SP, Brazil). Specimens to be relined of one surface, and control specimens were stored in distilled water at $37^{\circ} \mathrm{C}$ for $48 \mathrm{~h}$ to ensure saturation.

\section{Preparation of Relined Specimens}

Eighty-four denture resin rectangular specimens $(65 \times 10 \times 1.5 \mathrm{~mm})$ were placed in the lower portion of cast molds, which were prepared previously with dimesions of $65 \times 10 \times 3 \mathrm{~mm}$. Fourteen experimental subgroups were determined according to processing methods and reline materials $(n=6)$. The remaining $1.5 \mathrm{~mm}$ thickness of cast molds was filled with different reline materials. Processing methods of the materials and group codes used in this study are listed in Table 2. Heat-polymerization (for the water bath processing group) was performed in a thermostatically controlled water bath (Kavo EWL 5501, Kavo Electrotechnisches Werk GmbH, Germany). Microwave-polymerization was performed in a fiberreinforced plastic flask (FRP, H.K. type, G.C. Dental Indust. Corp. Tokyo, Japan) and polymerization was completed in a $2450-\mathrm{MHz}$ microwave oven with a rotating turntable (Vestel Goldstar ER 535 MT, Manisa, Turkey) with 1 cycle. Visible light cure polymerization was completed in Triad 2000 VLC Unit (Dentsply York Division, US). Eventually, relined specimens were made with using $1.5 \mathrm{~mm}$ thickness reline resin on $1.5 \mathrm{~mm}$ thickness denture base resin. The all relined specimens were measured with caliper and were immersed in $37^{\circ} \mathrm{C}$ distilled water for $48 \mathrm{~h}$ prior to the flexural test.

\section{Flexural Strength Tests}

The flexural strength test was conducted according to ISO Specification No. 20795-1:2013 for the denture base polymers. Specimens were subjected to three-point bending test on a support of $50 \mathrm{~mm}$ on a Universal test machine (Instron Model No 1195, Instron Ltd. England) with a cross-head speed of $5 \mathrm{~mm} / \mathrm{min}$ until fracture occurred to detected flexural strength. For flexural strength tests, the denture base resin surface was placed facedown for each of the composite specimens, imitating
Table 2. Abbreviations of Control Group (M) and Relined Test Groups according to the Polymerization Methods

\begin{tabular}{|c|c|}
\hline $\begin{array}{l}\text { Group } \\
\text { name }\end{array}$ & Polymerization cycles \\
\hline M & $\begin{array}{l}\text { Under hydrolic pressure for } 15 \mathrm{~min} \text { then } 20 \mathrm{~min} \text { at } \\
70^{\circ} \mathrm{C} \text {, then } 22 \mathrm{~min} \text { in water bath } 100^{\circ} \mathrm{C}\end{array}$ \\
\hline MM1 & $\begin{array}{l}\text { Under hydrolic pressure for } 15 \mathrm{~min} \text { then } 20 \mathrm{~min} \text { at } \\
70^{\circ} \mathrm{C} \text {, then } 22 \mathrm{~min} \text { in water bath } 100^{\circ} \mathrm{C}\end{array}$ \\
\hline MM2 & $\begin{array}{l}\text { Under hydraulic pressure for } 15 \mathrm{~min} \text {, then } 9 \mathrm{~h} \text { in } \\
\text { water bath at } 70^{\circ} \mathrm{C}\end{array}$ \\
\hline MM3 & $\begin{array}{l}15 \text { min under hydraulic pressure, then microwave- } \\
\text { polymerization for } 3 \mathrm{~min} \text { at } 500 \mathrm{~W}\end{array}$ \\
\hline MA1 & $\begin{array}{l}\text { Under hydraulic pressure for } 15 \mathrm{~min} \text {, then } 1 \mathrm{~h} \text { at } \\
70^{\circ} \mathrm{C}, 1 \mathrm{~h} 100^{\circ} \mathrm{C} \text { in water bath }\end{array}$ \\
\hline MA2 & $\begin{array}{l}\text { Under hydraulic pressure for } 15 \mathrm{~min} \text {, then } 9 \mathrm{~h} \text { in } \\
\text { water bath at } 70^{\circ} \mathrm{C}\end{array}$ \\
\hline MA3 & $\begin{array}{l}15 \text { min under hydraulic pressure, then microwave- } \\
\text { polymerization for } 3 \mathrm{~min} \text { at } 500 \mathrm{~W}\end{array}$ \\
\hline ML1 & $\begin{array}{l}\text { Under hydraulic pressure for } 15 \mathrm{~min} \text {, then } 90 \mathrm{~min} \text { at } \\
72^{\circ} \mathrm{C} \text {, then } 30 \mathrm{~min} 100^{\circ} \mathrm{C} \text { in water bath }\end{array}$ \\
\hline ML2 & $\begin{array}{l}\text { Under hydraulic pressure for } 15 \mathrm{~min} \text {, then } 9 \mathrm{~h} \text { in } \\
\text { water bath at } 70^{\circ} \mathrm{C}\end{array}$ \\
\hline ML3 & $\begin{array}{l}15 \text { min under hydraulic pressure, then microwave- } \\
\text { polymerization for } 3 \text { min at } 500 \mathrm{~W}\end{array}$ \\
\hline MO1 & $\begin{array}{l}\text { Autopolymerization for } 14 \text { min under hydraulic } \\
\text { pressure, then } 12 \mathrm{~h} \text { under clamp }\end{array}$ \\
\hline $\mathrm{MO} 2$ & $\begin{array}{l}15 \text { min under hydraulic pressure, then microwave- } \\
\text { polymerization for } 3 \mathrm{~min} \text { at } 500 \mathrm{~W}\end{array}$ \\
\hline MT1 & $\begin{array}{l}\text { Surface treatment with Triad bonding agent, then } \\
\text { light activation for } 10 \text { minute }\end{array}$ \\
\hline MT2 & $\begin{array}{l}\text { Chemical surface treatment with monomer, then } \\
\text { light activation for } 10 \text { minute }\end{array}$ \\
\hline MAM & $\begin{array}{l}15 \text { min under hydraulic pressure, then microwave- } \\
\text { polymerization for } 3 \mathrm{~min} \text { at } 500 \mathrm{~W}\end{array}$ \\
\hline
\end{tabular}

the clinical situation where the reline material is mostly under compression.

The flexural strength was calculated using the following formula: $\mathrm{S}=3 \mathrm{FL} / 2 \mathrm{bh}^{2}$;

$\mathrm{S}$; the flexural strength of specimen (MPa)

F; maximum load applied on the specimen at the time of fracture $(\mathrm{N})$

$\mathrm{L}$; the distance between two supports ( $\mathrm{mm}$ )

$\mathrm{h}$; the height of specimen measured immediately prior to water storage $(\mathrm{mm})$

$\mathrm{b}$; the width of specimen measured immediately prior to water storage $(\mathrm{mm})$. 


\section{Statistical Analysis}

The statistical analysis was performed by SPSS for windows version 18.0. Normality of the data was determined by the Shapiro-Wilk test. The homogeneity of variances was carried out by using Levene's test. The data were analyzed by one-way ANOVA. $\alpha=0.05$. Student t post-hoc test was used to compare the mean of flexural strength of each relined group.

\section{Results}

The mean and standard deviation values of flexural strength of control and relined groups are presented in Table 3. Statistical analysis revealed that intact denture base control specimens showed significantly higher flexural strength $(86.51 \pm 1.08 \mathrm{MPa})$ than those of all relined groups $(63.15 \pm 2.60 \mathrm{MPa}$ to $77.90 \pm 1.93 \mathrm{MPa})(\mathrm{p}<$ $0.001)$. Also, there were statistically significant differences in flexural strength among specimens relined with different materials and methods $(\mathrm{p}<0.05)$ as shown Table 3 .

Table 3. Mean and standard deviation (SD) of flexural strengths $(\mathrm{MPa})$ of control and relined test groups

\begin{tabular}{lc}
\hline & Flexural Strength \\
Group & Mean+SD \\
\hline M & $86.51 \pm 1.08 \mathrm{a}$ \\
MM1 & $77.90 \pm 1.93 \mathrm{~b}$ \\
MM2 & $68.33+1.93 \mathrm{c}, \mathrm{d}, \mathrm{f}$ \\
MM3 & $71.53+2.23 \mathrm{c}, \mathrm{d}, \mathrm{f}$ \\
MA1 & $70.44+1.66 \mathrm{c}, \mathrm{d}, \mathrm{f}$ \\
MA2 & $67.47+1.80 \mathrm{c}, \mathrm{d}, \mathrm{f}$ \\
MA3 & $73.16+5.08 \mathrm{~b}, \mathrm{f}$ \\
ML1 & $68.82+2.20 \mathrm{c}, \mathrm{f}$ \\
ML2 & $64.08 \pm 4.23 \mathrm{c}, \mathrm{f}$ \\
ML3 & $63.15 \pm 2.60 \mathrm{c}, \mathrm{f}$ \\
MO1 & $59.81 \pm 1.50 \mathrm{e}$ \\
MO2 & $67.98+3.91 \mathrm{f}$ \\
MT1 & $63.73+3.64 \mathrm{c}, \mathrm{e}$ \\
MT2 & $65.75+0.97 \mathrm{c}, \mathrm{e}$ \\
MAM & $72.20 \pm 4.78 \mathrm{~b}$ \\
\hline
\end{tabular}

Means followed by different letters represent statistical significance $(p<0.05)$ Means with superscript of the same letter indicate no significant difference $(p \geq 0.05)$

\section{Discussion}

This study demonstrated the effect of different reline materials and different polymerization types on the flexural strength of heat cured PMMA. All relined specimens showed lower flexural strength values than non-relined control specimens. Therefore, the null hypothesis that the denture relining materials have no effect on flexural strength of relined dentures was rejected.

The adaptation of removable dentures on the oral tissues is an important factor to obtain stability, retention and support. Residual ridge resorption is nautral process, which is resulted loss of adaptation of denture ${ }^{18}$. Therefore, the relining procedure often requires to provide the fit of the removable dentures. However, relining procedure may decrease the flexural strength of denture base and it is considered as negative effect ${ }^{19}$. In this study, it was observed that the control group have significantly highest flexural strength mean value.

The function of reline materials relates with their characteristics, mechanical properties and adhesion quality at interface ${ }^{10}$. Some studies were stated that autopolymerized reline resins decrease the flexural strength of heat polymerized denture base material ${ }^{12,13}$. In accordance with this result, in this study, the lowest flexural strength was detected in autopolymerized reline specimens (59.81 MPa). Autopolymerized reline acrylic resins content a higher degree of residual monomer because chemical activator achieves a low degree of conversion compared to heat activation ${ }^{7,20}$. Consequently, this residual monomer, which acts as a plasticizer, impairs the mechanical properties of denture base ${ }^{7,21}$. Different polymerization techniques may be applied to increase the degree of conversion and decrease content of residual monomer such as immersion in hot water and microwave irradiation $^{7,22-24}$.

Microwave irridation, causes positively movement effect on acrylic resin monomer and internal heat is induced with this movement. The heat is scattered more homogenously and also residual monomer content and porosity are decreased ${ }^{25,26}$. Moreover, the polymerization is completed in short time period. Thus, microwave irridation provides to increase the strength of acrylic resin. In this study, the strength of special microwave acrylic resin (MAM) was the strongest relined group except that were relined using the same material (MM1) as the denture base itself and there was no significant difference between them. It was observed that microwave polymerization significantly increased the flexural strength values of autopolymerized acrylic resin and the polymerization of microwave energy of autopolymerized resin can be advantageous for the durability of the relining process due to short polymerization time and low owen power. Minimize level of residual monomer and toxicity reduction may be obtained with using microwave irradiation on heat polymerized acrylic 
resins with suitable combination of power and time ${ }^{27}$. On the other hand, the fact that visible light cured reline resin specimens showed similar resistance with autopolymerized reline resin, and it was revealed that visible light cure resin can be an alternative reline material to autopolymerized resin. Surface preparations may influence reline bond strength of visible light cured urethane-based dimethacrylate resin. In our study, the effect of monomer wettingon the flexural strength value, although the adhesive was applied on the denture base according to the manufacturer's recommendation for the relined specimens with visible light cure resin, is statistically insignificant increase.

The bond strength between denture base and reline material is crucial factor for flexural strength of relined denture base $\mathrm{e}^{19,28}$. If the bond of denture base and reline material is weak, the delamination will be occurred during function ${ }^{14,29}$ and flexural strength of denture base will be unavoidably decreased ${ }^{30}$. It may be probably explained by molecular interaction of active site between two surfaces. The low bonding ability of reline materials to denture base decrease the strength of denture and delamination occurs. Also, the weakness of the bonding causes fracture of relined denture base ${ }^{29}$. The chemical similarity between the denture base and reline materials may have created a formation of an interpenatraining network and a diffuse interface. It was reported that reline resins, which have high moleculer weight monomers, may not penetrate into polymer structure of denture base resin ${ }^{31,32}$. Besides, Hout et al. ${ }^{14}$ evaluated the effect of three different self-cured hard relining materials on flexural strength of PMMA denture base material. It was stated that flexural strength of specimens relined with PMMA was significantly higher than relined with PEMA. Another explanation of decrease on flexural strength may be internal stress of denture base resin due to curing process of reline materials. Recurrent or long-term heat application could be lead to crack propagation in denture base. As a result, the strength and rigidity of realine resin may be affected negatively ${ }^{31}$. Similarly, in this study, the specimens which were polymerized in water bath in long-term period (MM2, MA2, ML2), showed lower flexural strength values than other polymerization techniques.

The limitation of this study was that thermal differences and loading stresses, which were exposed during clinical usage of the prosthesis, were disregarded. The specimens only were stored in water at $37^{\circ} \mathrm{C}$ to simulate oral conditions. Further studies are necessary to evaluate these aspects.

\section{Conclusions}

Within the limitations of this in vitro study, the following conclusions were found:
1- The relined specimens showed lower flexural strength, as compared to the intact specimens (control group),

2- Flexural strength values were different among relined denture bases,

3- Relining with same material and special microwave acrylic resin of denture base showed the highest flexural strength in relined denture bases,

4- Relining with autopolymerized acrylic resins showed the lowest flexural strength,

5- Relining with microwave-cured acrylic resins were as strength as the relining with the same material.

\section{References}

1. Uzun G, Hersek N, Tinçer T. Effect of five woven fiber reinforcements on the impact and transverse strength of a denture base resin. J Prosthet Dent, 1999;81:616-620.

2. Köroğlu A, Özdemir T, Usanmaz A. Comparative study of the mechanical properties of fiber-reinforced denture base resin. J App Polymer Sci, 2009;113:716-720.

3. Silva CS, Machado AL, Chaves CAL, Pavarina AC, Vergani CE. Effect of thermal cycling on denture base and autopolymerizing reline resins. J Appl Oral Sci, 2013;21:219-224.

4. Kovacić I, Celebić A, Zlatarić DK, Petricević N, Buković D, Bitanga $\mathrm{P}$, et al. Decreasing of residual alveolar ridge height in complete denture wearers. A five year follow up study. Coll Antropol, 2010;34:1051-1056.

5. Mercier P, Bellavance F. Effect of artificial tooth material on mandibular residual ridge resorption. J Can Dent Assoc, 2002;68:346-350.

6. Zlatarić DK, Celebić A, Kovacić I, Vitasović BM. Linear vertical jaw resorption potential in elderly complete denture wearers: a ive-year followup study. Coll Antropol, 2008;32:907-912.

7. Seo RS, Vergani CE, Giampaolo ET, Pavarina AC, Machado AN. Effect of a Post-Polymerization Treatments on the Flexural Strength and Vickers Hardness of Reline and Acrylic Denture Base Resins. J Oral App Sci, 2007;15:506511.

8. Haywood J, Basker RM, Watson CJ, Wood DJ. A comparison of three hard chairside denture reline materials. Part I. Clinical evaluation. Eur J Prosthodont Restor Dent 2003;11:157-163.

9. Matsumura H, Tanoue N, Kawasaki K, Atsuta M. Clinical evaluation of a chemically cured hard denture relining material. J Oral Rehabil, 2001;28:640-644.

10. Wady AF, Machado AL, Vergani CE, Pavarina AC, Giampaolo ET. Impact strength of denture base and reline acrylic resins subjected to long-term water immersion. Braz Dent J, 2011;22:56-61.

11. Takahashi Y, Chai J, Mawaguchi M. Strength of relined denture base polymers subjected to long-term water immersion. Int J Prosthodont, 2000;13:205-208.

12. dos Santos Nunes Reis JM, Vergani CE, Pavarina AC, Giampaolo ET, Machado AL. Effect of relining, water storage and cyclic loading on the flexural strength of a denture base acrylic resin. J Dent, 2006;34:420-426. 
13. Seo RS, Murata H, Hong G, Vergani CE, Hamada $T$. Influence of thermal and mechanical stresses on the strength of intact and relined denture bases. J Prosthet Dent, 2006;96:59-67.

14. Hout D, Wonglamsam A, Kanchanavasita W. Flexural strength of relined denture base using different thickness of self-cured relining material. M Dent J, 2017;37:223-232.

15. Machado AL, Bochio BC, Wandy AF, Jorge JH, Canevarolo SV, Vergani Jr CE. Impact strength of denture base and reline acrylic resins: an in vitro study. J Dent Biomech, 2012;3:1758736012459535.

16. Da Cruz Perez LE, Machado AL, Vergani CE, Zamperini CA, Pavarina AC, Canevarolo SV Jr. Resistance to impact of cross-linked denture base biopolymer materials: Effect of relining, glass flakes reinforcement and cyclic loading. $\mathrm{J}$ Mech Behav Biomed Mater, 2014;37:33-41.

17. International Standards Organization. Dentistry-Base polymers- Part 1: Denture base polymers. ISO 20795-1. International Standards Organization, Geneva, Switzerland; 2013.

18. Tallgren A. The continuing reduction of the residual alveolar ridges in complete denture wearers: a mixed longitudinal study covering 25 years. J Prosthet Dent, 2003;89:427-435.

19. Polyzois GL, Lagouvardos PE, Frangou MJ. Flexural and bond strengths of relined denture polymers assessed by fourpoint bending tests and Weibull analysis. Gerodontology, 2012;29:e543-e552.

20. Vallittu PK. The effect of surface treatment of denture acrylic resin on the residual monomer content and its release into water. Acta Odontol Scand, 1996;54:188-192.

21. Lee SY, Lai YL, Hsu TS. Influence of polymerization conditions on monomer elution and microhardness of autopolymerized polymethyl methacrylate resin. Eur J Oral Sci, 2002;110:179-183.

22. de Mello JAN, Braun KO, Rached RN, Del Bel Cury AA. Reducing the negative effects of chemical polishing in acrylic resins by use of an additional cycle of polymerization. J Prosthet Dent, 2003;89:598-602.

23. Urban VM, Machado AL, Oliveira RV, Vergani CE, Pavarina AC, Cass QB. Residual monomer of reline acrylic resins Effect of water-bath and microwave postpolymerization treatments. Dent Mater, 2007;23:363-368.

24. Vergani CE, Seo RS, Pavarina AC, dos Santos Nunes Reis JM. Flexural strength of auto polymerizing denture reline resins with microwave postpolymerization treatment. J Prosthet Dent, 2005;93:577-583.
25. Ng ET, Tan LH, Chew BS, Thean HP. Shear bond strength of microwaveable acrylic resin for denture repair. J Oral Rehabil, 2004;31:798-802.

26. Rached RN, Powers JM, Del Bel Cury AA. Repair strength of autopolymerizing, microwave, and conventional heatpolymerized acrylic resins. J Prosthet Dent, 2004;92:79-82.

27. Azzari MJ, Cortizo MS, Alessandrini JL. Effect of the curing condition on the properties of an acrylic denture base resin microwave polymerized. J Dent, 2003;31:463-468.

28. Sun Y, Song SY, Lee KS, Park JH, Ryu JJ, Lee JY. Effects of relining materials on the flexural strength of relined thermoplastic denture base resins. J Adv Prosthodont, 2018;10:361-366.

29. Da Cruz Perez LE, Machado AL, Canevarolo SV, Vergani CE, Giampaolo ET, Pavarina AC. Effect of reline material and denture base surface treatment on the impact strength of a denture base acrylic resin. Gerodontology, 2010;27:62-69.

30. Chai J, Takahashi Y, Kawaguchi M. The flexural strengths of denture base acrylic resins after relining with a visiblelight-activated material. Int J Prosthodont, 1998;11:121-124.

31. Archadian N, Kawano F, Ohguri T, Ichikawa T, Matsumoto N. Flexural strength of rebased denture polymers. J Oral Rehabil, 2000;27:690-696.

32. Minami H, Suzuki S, Minesaki Y, Kurashige H, Tanaka T. In vitro evaluation of the influence of repairing condition of denture base resin on the bonding of autopolymerizing resins. J Prosthet Dent, 2004;91:164-170.

Conflict of Interests: Nothing to declare.

Financial Disclosure Statement: Nothing to declare.

Human Rights Statement: None required.

Animal Rights Statement: None required.

Received on September 3, 2020.

Revised on October 28, 2020.

Accepted on December 20, 2020.

Correspondence:

Ozlem Gurbuz Oflezer

Bahcelievler Oral and Dental Health Hospital

Ministry of Health, Bahcelievler, Istanbul/Turkey

e-mail: zlmgrbz@yahoo.com 